\title{
Phytochemical and Antioxidant Capacity Test on Turmeric Extract (Curcuma Longa) Traditionally Processed in Bali
}

\author{
Pande Ayu Naya Kasih Permatananda ${ }^{1}$, Anak Agung Sri Agung Aryastuti ${ }^{2}$, \\ Putu Nita Cahyawati ${ }^{3}$, Desak Putu Citra Udiyani ${ }^{4}$, D. Wijaya ${ }^{5}$, I Gde Suranaya Pandit ${ }^{6}$, Anak \\ Agung Ngurah Mayun Wirajaya ${ }^{7}$ \\ 1,2,3,4,5Faculty of Medicine and Health Science, Universitas Warmadewa \\ ${ }^{6,7}$ Faculty of Agriculture, Universitas Warmadewa \\ Email : 1,2,3,4 nayakasih@gmail.com
}

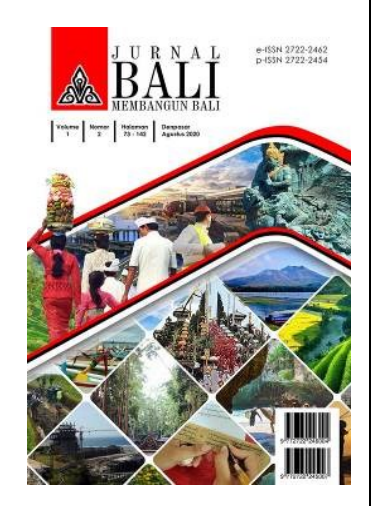

Article History

Received on 24 June 2020

Revised on 27 June 2020

Accepted on 2 July 2020

\begin{abstract}
Abstrak
Tujuan: Tujuan dari penelitian ini adalah untuk menentukan cara dan tujuan penggunaan kunyit oleh orang Bali, serta kandungan fitokimia dan kapasitas antioksidan dari ekstrak kunyit yang secara tradisional diproses di Bali.

Metode Penelitian: Metode dan tujuan memanfaatkan kunyit diperoleh melalui observasi dan wawancara dengan 900 responden Bali. Tes fitokimia kuantitatif meliputi kadar pati, protein, flavonoid, tanin, fenol dan vitamin $C$ dan secara kualitatif untuk keberadaan triterpen, steroid, alkaloid, dan saponin. Kapasitas antioksidan diukur menggunakan metode DPPH.

Temuan: Ditemukan hanya $36,8 \%$ responden yang pernah menggunakan kunyit sebagai obat tradisional. Pemanfaatan kunyit itu sebagian besar dalam bentuk loloh atau minuman tradisional. Hasil uji fitokimia menunjukkan ekstrak kunyit mengandung $67,38 \%$ pati, protein $3,42 \%$, flavonoid $2709,39 \mathrm{mg} / 100 \mathrm{gr}$, tanin $291,64 \mathrm{mg} / 100 \mathrm{gr}$, fenol $1584,04 \mathrm{mg} / 100 \mathrm{gr}$, dan vitamin C $0,06 \mathrm{mg} / 100 \mathrm{gr}$. Secara kualitatif, ekstrak kunyit mengandung triterpen, alkaloid, dan saponin, tetapi tidak mengandung steroid. Kapasitas antioksidan ekstrak kunyit adalah 70,9 mg/L GAEAC.

Implikasi: Ekstrak kunyit adalah obat tradisional yang dibuat dari alam yang paling umum digunakan oleh orang Bali dan sangat potensial untuk dikembangkan sebagai antibakteri, antioksidan, antiinflamasi, atau manfaat lain yang masih perlu diteliti lebih
\end{abstract} lanjut.

Kata kunci: uji kapasitas fitokimia dan antioksidan, ekstrak kunyit, Bali.

\begin{abstract}
Purpose: The purpose of this study was to determine the ways and objectives of the use of turmeric by Balinese, as well as the phytochemical content and antioxidant capacity of turmeric extract which is traditionally processed in Bali.

Research methods: The method and purpose of utilizing turmeric were obtained through observation and interviews with 900 Balinese respondents. Quantitative phytochemical tests include starch, protein, flavonoid, tannin, phenol and vitamin $\mathrm{C}$ levels and qualitatively for the presence of triterpenes, steroids, alkaloids, and saponins. Antioxidant capacity was measured using the DPPH method.

Findings: Through this research, we found there were only $36.8 \%$ of respondents had ever used turmeric as a traditional medicine. Utilization of turmeric was mostly in the form of loloh or traditional drinks. Phytochemical test results showed turmeric extract had $67.38 \%$ starch, $3.42 \%$ protein, $2709.39 \mathrm{mg} / 100 \mathrm{gr}$ flavonoids, tannins 291.64 $\mathrm{mg} / 100 \mathrm{gr}$, phenol $1584.04 \mathrm{mg} / 100 \mathrm{gr}$, and vitamin C $0.06 \mathrm{mg} / 100 \mathrm{gr}$. Qualitatively, turmeric extract contained triterpenes, alkaloids, and saponins, but did not contain steroids. The antioxidant capacity of turmeric extract was $70.9 \mathrm{mg} / \mathrm{L}$ GAEAC.

Implications: Turmeric extract is a traditional medicine made from nature that is most commonly used by Balinese and very potential to be developed as an antibacterial, antioxidant, anti-inflammatory, or other benefits that still need further investigation.
\end{abstract}

Keywords: phytochemical and antioxidant capacity test, turmeric extract, Bali 


\section{INTRODUCTION}

Since long time ago, Indonesian people used nature for their survival. One of the natural products that have been developed is herbs that are used as traditional medicine to cure various diseases (Sari et al, 2015). Traditional medicine derived from plants is a manifestation of the active participation of the community in solving health problems and the role has been recognized by various nations in improving the degree of public health. World Health Organization (WHO) recommends the use of traditional medicines including herbal medicines in the maintenance of public health, prevention and treatment of diseases, especially for diseases that have not yet found a cure such as chronic diseases, degenerative diseases and cancer (Agustina, 2016).

Indonesian people mix various kinds of traditional medicinal plants into traditional herbal drink, Indonesian called them as jamu in Java, while in Bali they are called as loloh. Both jamu and loloh not only have medicinal properties but also have historical values and traditions that need to be preserved. Based on qualitative research conducted in Java and Bali, Turmeric was included as one of the ten most traditional herbal medicine in Indonesia, including in Bali [1].

Turmeric belongs to the zingiberacea group which is traditionally widely used as herbs, cooking spices, food ingredients, preservatives, and food coloring in Asian countries like Indonesia. It is also used in social and religious ceremonies mentioned in Ayurvedic and some folk medicines, namely Usadha in Bali against various ailments, such as gastric, hepatic, gynecological, dan infectious disease (Tavir et al, 2017; Gupta et al, 2013; Hasan, 2014). In particular, some scientific research stated that turmeric have various pharmacology properties, for instance as antiinflammatory, antioxidant, antitumor, antibacterial, anticoagulant and antidiabetic due to its free radical scavenging activities (Hasan, 2015; Sera et. al, 2019; Kim, 2016). Antioxidant properties and capacities of some turmeric have already been studied, however there are least knowledge and scientific data on the composition and activities of turmeric's antioxidant that traditionally processed in Bali. Thus, this present study was aimed to describe the use of turmeric for herbal medicine in Bali, determine antioxidant level and capacities of Balinese turmeric extract.

\section{RESEARCH METHOD}

This research was carried on based on explorative quantitative method. We collected data on the use of turmeric as traditional medicine from 900 respondents 
spread across 9 districts in Bali by conducting interviews and observations. Turmeric usage data in this study includes the method and purpose of utilization.

The sample used was 500 grams of fresh turmeric, then finely chopped following the traditional procedure carried out in Bali. The sample is then placed in a closed jar for further procedures.

Samples were extracted by using water as a universal solvent that can extract various active compounds contained in plants (Ahmad, 2006). The use of water was also intended to follow procedures commonly used by the Balinese people. A total of $500 \mathrm{~g}$ of fresh samples were boiled using $2500 \mathrm{ml}$ of water solvent at $90^{\circ} \mathrm{C}$ for 30 minutes. The extract was then filtered using filter paper and the solvent was evaporated using a rotary evaporator.

Phytochemical tests were carried out to determine the content of compounds contained in turmeric extracts. Phytochemical compound analysis includes qualitative and quantitative tests. Quantitative measurement, such as Starch test was carried out using the Luf Schrool method and titration, protein levels were determined by the Kjeldahl method, and spectrophotometers were used to measure levels of phenols, tannins, flavonoids and vitamin $\mathrm{C}$. We conducted several qualitative assesment to detect triterpenoid, steroid, and alkaloid content in turmeric extract. For testing alkaloids, we added dragendorff reagents to the extract and red precipitate showed positive. Meanwhile, to detect triterpenoid and steroid contents, we dissolved the extract with chloroform, then added anhydrous acetate and $\mathrm{H} 2 \mathrm{SO}$, brownish or violet rings indicated positive triterpenes, while positive steroids were marked in green.

Antioxidant activity of the extracts was determined by 1,1-diphenyl2picrylhydrazyl (DPPH) assay which is $0.1 \mathrm{ml}$ of turmeric extract was added into 0.4 $\mathrm{mM}$ DPPH solution and incubated for $30 \mathrm{~min}$. Absorbance was measured at wavelength $516 \mathrm{~nm}$. We calculated DPPH radical scavenging activity by comparing the inhibition rate with sample blank (Sera et. al, 2019; Kim, 2016, Ahmad, 2006; Heo, 2005).

\section{RESULT}

From 900 respondents, we found there were 332 (36.8\%) respondents use turmeric as herbal medicine. Making jamulloloh was the most common method used by the Balinese in processing turmeric, as shown in Figure 1. More than twenty percent of turmeric was used by Balinese to overcome gastric disorders, can be seen in Figure 2 .

Phytochemical test results [Table 1] showed that turmeric traditionally processed in Bali contained starch, protein, antioxidant compounds such as flavonoids, 
phenols, tannins, and vitamin C which were quite large. Qualitatively, turmeric consisted of triterpenes, alkaloids, and saponins, but did not have steroids. By using the DPPH assay, turmeric antioxidant capacity was obtained at $70.9 \mathrm{mg} / \mathrm{L}$ GAEAC.

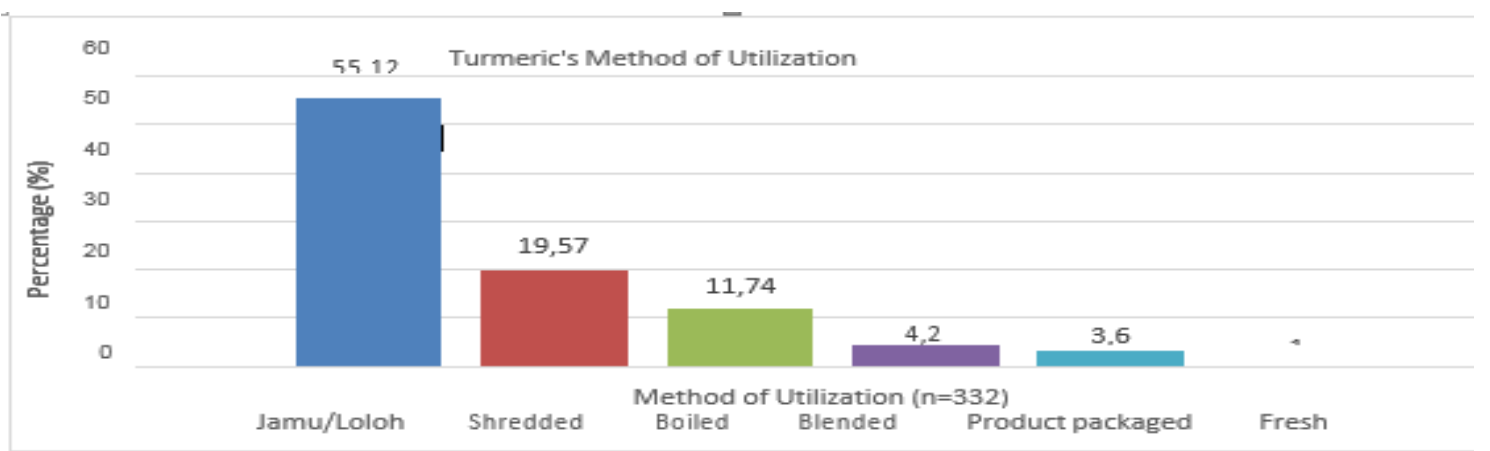

Figure 1. Turmeric's Method of Utilization by Balinese

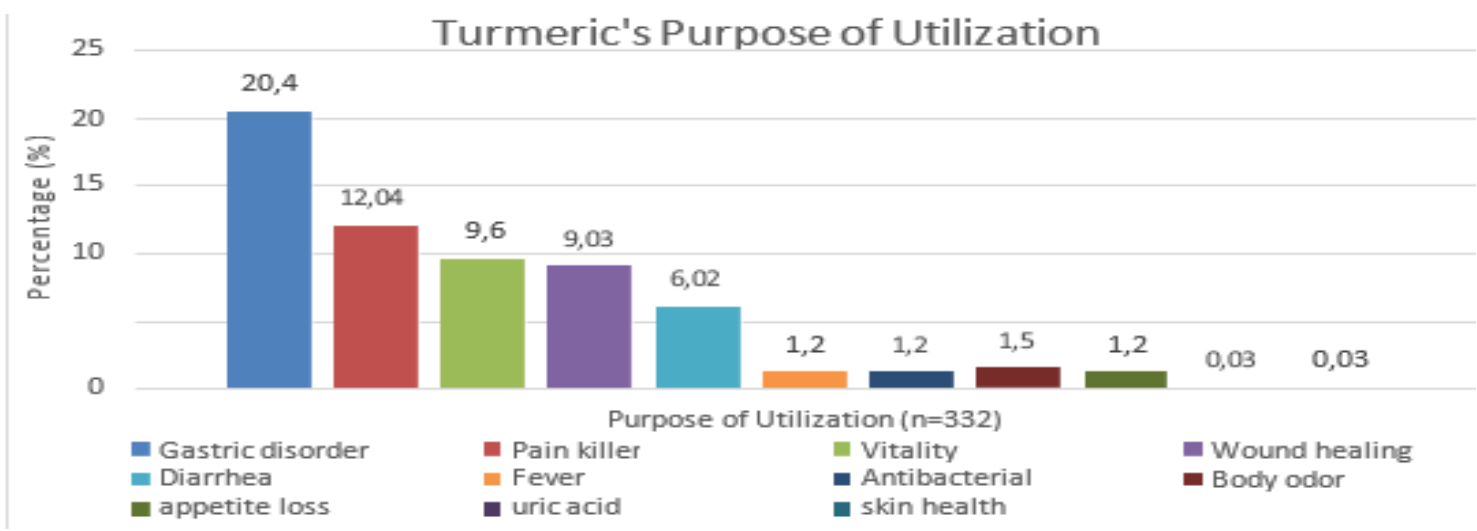

Figure 2. Turmeric's Purpose of Utilization by Balinese

Table 1. Pythochemical and Antioxidant CapacityTest Result

\begin{tabular}{llc}
\hline No & Type of Examination & Result \\
\hline 1 & Starch & $67.38 \%$ \\
2 & Protein & $3.4168 \% \mathrm{bw}$ \\
3 & Flavonoid & $2709.39 \mathrm{mg} / 100 \mathrm{gr}$ \\
4 & Tanin & $291.64 \mathrm{mg} / 100 \mathrm{gr}$ \\
5 & Fenol & $1584.04 \mathrm{mg} / 100 \mathrm{gr}$ \\
6 & Vitamin C & $0.06 \mathrm{mg} / 100 \mathrm{mg}$ \\
7 & Antioxidant capacity & $70.9 \mathrm{mg} / \mathrm{L} \mathrm{GAEAC}$ \\
\hline
\end{tabular}

\section{DISCUSSION}

Indonesia is one of the countries in Asia with high use of turmeric. Turmeric has high economic and cultural values and is widely cultivated, used as a medicinal plant, planted ornamentally and is culturally important (Subositi, 2019; Sathi, 2017). The biggest producer of turmeric in the world was in India. India has 150.000 hectares of land for turmeric cultivation, the majority of which is used to meet 
domestic needs as condiment and occupies, and only about $8 \%$ is exported periodically (Sathi, 2017).

Turmeric belong to genus Curcuma is a member of the Zingiberaceae family and consist of aproximately 80 species. Not only spread in Southeast Asian friends, South Asia and China, several species of curcuma are also found in Asia and the Pacific (Chen et al, 2013). Curcuma is a herbaceous plant. It has a pseudostem. The rhizome is thick and fleshy with a compound flowersappears at the end of the stem or arises separately from the rhizome. The inside of the rhizome has a variety of colors from white, yellow, beige through orange, blue, bluish green and black (Sirirugsa, 2007). Rhizome used for traditional ingredients, aroma enhancers, and natural dyes (Zhang et al, 2018). Indonesia is reported to have 15 curcuma species and Curcuma longa or turmeric is the most widely used curcuma species (Subositi, 2019; Sathi, 2017; Chen, 2013).

Based on a research in Central Java, they found that curcuma longa was the most widely used species as herbal medicine to treat 71 symptoms of disease, with gastritis as the most often treated conditions, followed by pre and post partum condition, and liver disease. Only four conditions in that research that did not use Curcuma longa, namely insect repellent, slimming treatment, epilepsy, and insomnia (Subositi, 2019). In this study, we also found gastric disorder inlude nausea, vomiting, and epigastrial pain were the most purpose of turmeric utilization in Bali. According to Formularium Herbal Asli Indonesia, the use of turmeric to treat gastric problem or gastritis has evidence based medicine grade $\mathrm{C}$, which is the evidence was still unclear or conflicting (Kemenkes, 2016). While previous literature mentioned that turmeric has a protective effect on gastrointestinal tract. The component of turmeric is belived to be able to inhibit intestinal spasm and increase gastrin, secretin, bicarbonate and pancreatic enzyme secretion. It can also inhibit the formation of peptic ulecer and significantly increase mucosal secretion as defense factor against gastrointestinal insults, such as alcohol, stress, caffeine, and some drugs (Subositi, 2019; Sathi, 2017; Chen, 2013).

Assesing antioxidant properties and extraction yield, likes in this study, is depend on both the extraction method and the type of solvent used during the extraction. The various antioxidant compound swith different chemical characteristics and polarities of plant materials are soluble in different solvents (Tanvir, 2017). We used water which is an organic polar compound that is suitable for extraction of various bioactive phytochemical. The results of the examination of starch and protein levels in this turmeric extract are not much different from the composition of starch 
and protein in turmeric in general (Sathi, 2017). Flavonoids, tannins, phenols are phytochemical compounds that have a role to maintain the taste and color, and also have important contributions in health-promoting activities as free radical scavenger. Vitamin C or ascorbic acid is a powerful antioxidant compound that not only interacts directly with ROS but also contributes to the regeneration of other antioxidants. The content of vitamin $C$ in turmeric ranged from 0.03 to $0.11 \mathrm{mg} / 100 \mathrm{~g}$ of turmeric and the content of vitamin $\mathrm{C}$ obtained in turmeric extract in this study was not much different, namely $0.06 \mathrm{mg} / 100 \mathrm{~g}$. Previous research stated that ethanolic turmeric extract exhibits higher antioxidant capacity than aqueous turmeric extract. Our traditionaly processed turmeric extract can be belong to aqueous extract. Antioxidant capacity that are reflected by free radical scavenging activities may be attributed to the high contents of phenolics and flavonoids with a higher reducing capacity (Chen, 2013). Turmeric extract in this research has been shown natural antioxidant properties from their levels of tannin, phenols, flavonoids, vitamin $C$, and the appearance of triterpenes, alkaloids, and saponins. But in this study, turmeric extract did not have steroid content which can give an idea of the potentially harmless side effects of turmeric extract. The steroid content of herbal medicine could be a potent anti-inflammatory properties, but the high steroid content can cause adverse drug event that harmful to the body (Patel, 2019; Permatananda, 2018).

\section{CONCLUSION}

Turmeric extract is a traditional medicine made from nature that is most commonly used by Balinese. Most Balinese process turmeric into jamu/loloh to treat various diseases, most of which are gastric diseases. Despite of some use of turmeric in medicine is still unclear, turmeric is very potential to be developed as an antibacterial, antioxidant, anti-inflammatory, or other benefits that still need further investigation.

\section{REFERENCES}

Agustina S 2016 The Inhibiotin of Typhonium flagelliforme lodd Blume Leaf Extract on COX-2 Expression of WiDr Colon Cancer Cells Asian Pasific Journal of Tropical Biomedicine 6(3) p251- 255.

Ahmad I, Farrukh A, Mohammad O 2006 Modern Phytomedicine: Turning Medicinal Plants into Drugs (Winheim, Germany: Wiley-VCH).

Chen J, Xia N, Zhao J, Chen J, Henny R J 2013 Chromosome Numbers and Ploidy Levels of Chinese Curcuma Species Hortscience 48 (5) p 525-530. 
Gupta S C, Sung B, Kim J H, Prasad S, Li S, Aggarwal B B 2013 Multitargeting by Turmeric, The Golden Spice: From Kitchen to Clinic Molecular Nutrition and Food Research 57(9) p 1510-1528.

Hasan M, Mahmud M 2014 The Contribution of Turmeric Research and Development in The Economy of Bangladesh: An Ex-Postanalysis International Journal of Agricultural Research, Innovation and Technology 4(1) p1-10.

Heo S J, Park E J, Lee K W, Jeon Y J 2005 Antioxidant Activities of Enzymatic Extracts from Brown Seaweeds Bioresource Technology 96 p1613-1623

Kim D H 2016 Effects of Turmeric (Curcuma longa L) on The Physiochemical Characteristics of Kochujang Druing Fermentation Journal of Applied Biological Chemistry 56 p101-107.

Kim D W, Lee S M, Woo H S 2016 Chemical Constituents and Anti-inflammatory Activity of The Aerial Parts of Curcuma longa Journal of Functional Foods 26 p485-493.

Sari I D, Yuniar Y, Siahaan S, Riswati, Syaripuddin M 2015 Tradisi Masyarakat dalam Penanaman dan Pemanfaatan Tanaman Obat Lekat di Pekarangan Jurnal Kefarmasian Indonesia 5(2) p123- 132.

Sathi A S 2017 A Review on Pharmacological and Cosmeceutical Properties of Curcuma Longa Intl J Pharmaceut Sci Res 2(1) p9-16

Sera K, Seok Chun K, Yoon Sook K, Sang Keun H, Ho Young P, Yongkon P, Sang Hoon L 2019 Determination of Curcuma longa L. (Turmeric) Leaf Extraction Conditions Using Response Surface Methodology to Optimize Extraction Yield and Antioxidant Content 2019 Journal of Food Quality p1-8.

Sirirugsa P, Larsen K, Maknoi C 2007 The genus Curcuma L (Zingiberaceae): distribution and classification with reference to species diversity in Thailand Gard Bull Sing 59 (2) p203- 220.

Subositi D, Wahyono S 2019 Study of The Genus Curcuma in Indonesia Used As Traditional Herbal Medicine BIODIVERSITAS 20(5) p 2085-4722.

Tanvir E M, Hossen M S, Hossain M F, Afroz R, Gan S H, Khalil M I, Karim N 2017 Antioxidant Properties of Popular Turmeric (Curcuma longa) Varieties from Bangladesh Journal of Food Quality p1-8.

Zhang L, Wei J, Yang Z, Chen F, Xian Q, Su P, Pan W, Zhang K, Zheng X, Du Z 2018 Distribution and diversity of twelve Curcuma species in China Nat Prod Res 32 (3) p327-330. 
142 | Pande Ayu Naya Kasih Permatananda, Anak Agung Sri Agung Aryastuti, dkk 